\title{
The Impact of the China's
}

\section{Province-Managing-County Reform on Economic Growth in the Short Term and Long Term}

\author{
Lingjing Wu \\ Jinan University, Gaungzhou, China \\ Email: tansywu2016@163.com
}

How to cite this paper: $\mathrm{Wu}, \mathrm{L} . J .(2017)$ The Impact of the China's Province-Managing-County Reform on Economic Growth in the Short Term and Long Term. Modern Economy, 8, 1357-1365. https://doi.org/10.4236/me.2017.811091

Received: October 1, 2017

Accepted: November 25, 2017

Published: November 28, 2017

Copyright $\odot 2017$ by author and Scientific Research Publishing Inc. This work is licensed under the Creative Commons Attribution International License (CC BY 4.0).

http://creativecommons.org/licenses/by/4.0/

\begin{abstract}
We use panel data from 1995 to 2012 to examine the causal relationship between the China's province-managing-county reform (PMC) and the economic growth. In the identification method, we choose the difference-in-differences method by the software of STATA. We find that the PMC reform on has a negative effect on economic growth in the short-term, and has a positive effect on economic growth in the long-term. The main reason for the differences is to promote reform of infrastructure spending growth, in the short-term, the effect is lagged, but in the long term, it will benefit from that. Otherwise, reform makes the urban wage increase, than promote consumption, than the total amount of investment will increase. At last, will have a positive impact on economic growth. Overall, the reform has a positive effect on economic growth in the long term.
\end{abstract}

\section{Keywords}

China's Province-Managing-County Reform, Economic Growth, In the Short and Long Term, DID

\section{Introduction}

Referring to the theory of corporate governance, we know that flat management structure is conducive to solve information asymmetry and moral hazard and other principal-agent issues. So, does the government hierarchy have the same conclusion? This question has become a problem for scholars to explore. In theory, the decentralization of government power is conducive to economic 
growth and no clear conclusion [1] [2].

There has been a lack of examples of the impact of changes in government levels on economic performance, and it was not until 2003 that the Chinese government introduced the reform of PMC to provide evidence for the flattening of government structure. The purpose of the reform is to reduce the level of government through financial province and county system, and to develop the provincial government and county from the existing city and county, and finally optimize the organizational structure of the government. The relevant documents "the Ministry of Finance on promoting direct provincial supervision of County Finance Reform Opinions" is the main content of payments in the division of intergovernmental transfer payment, financial transactions, and budget, year-end settlement and other aspects, directly linked to the city and county finance and finance related business development.

At the same time, the discussion on the reform of the provincial town has continued since the policy. Li et al. argue that the decentralization of government structures increases taxes and transfers within government; however, it is difficult for provincial governments to supervise county-level governments because of the widening of provincial-level government management in the provinces [3]. The public expenditure and the increase in economic growth expenditure in the straight pipe counties are reduced, and the problem of land corruption is serious. In the new historical period, the urgent need for local governments to change their functions to achieve coordinated economic and social development, simply hope that the financial system reform is not enough to fundamentally solve the problem may even be counterproductive [4]. Lu agrees that deepen the decentralization reform and give the grassroots government greater autonomy decision-making power, will significantly increase the proportion of infrastructure spending, reduce education and other livelihood services accounted for the proportion of expenditure [5]. However, Guoagree that the provincial straight county reform to a certain extent, promote the county's economic growth. Some people think that the PMC reform is intended to solve the urban areas of the financial resources of the exploitation and encroachment to increase grass-roots government revenue, and promote county economic development [6]. The 18th Party Congress, the Third Plenary Session of the 18th Party clearly pointed out that the conditions of the place to explore the promotion of the provincial direct management of the county (city) system reform. To sum up, we can see that in the theory and mechanism design, all aspects tend to flatten the government structure is conducive to stimulate the county's economic vitality, promote county economic development. However, there are also a large number of excellent literature empirical results shows that the Chinese government structure flat on economic growth and the supply of public goods is a negative impact [7].

On the basis of trying to verify the effect of provincial reform on economic performance, this paper explores the motive of the government to further promote the reform of the PMC by the empirical analysis of double difference method. 


\section{Data and Variable Description}

1) Sample size and description

The 171 counties implemented PMC reform in 2003 and 2004 are treated as treatment group and the 831 counties has not implemented the reform from 2003 years to 2012 are treated as the control group.

2) Data sources

1. Chinese provinces Statistical Yearbook: 1995 to 2012 County-level GDP, urban household income and household income;

2. The national prefecture and county finance statistics 1995-2009: county-level financial information;

3. China population census 2000: county-level population;

4. The pilot data comes from central government documents or provincial government documents.

3) Statistical analysis

We divide the variables into two groups, the county conduct the pmc and non-pmc. And Table 1 shows the statistical analysis of dependent variables.

\section{Empirical Model and Empirical Analysis}

1) Empirical Model

This paper selects double difference method to identify the PMC reform effect. Double difference method is a very important method to evaluate the effect of policy. Technically, the double difference method can eliminate the difference between the initial value of the treatment group and the control group, and the influence of the time trend on the accuracy of the estimation coefficient [8].

$$
y_{i t}=\alpha_{i}+\beta P M C_{i t}+\gamma_{t}+\varepsilon_{i t}
$$

The $i$ represents a different county; $t$ means different years; $y_{i t}$ represents dependent variables, such as the GDP growth; $\alpha_{i}$ are fixed effects, capturing all the time-invariant characteristic of the counties which might influence the outcome of interest; $\gamma_{t}$ indicates the time fixed effects, controlling for nation-wide shocks in a particular year likely to have affected all counties in a similar manner; and $\varepsilon_{i t}$ is the error term.

$P M C_{i t}$ is the regressor of interest, indicating the county's PMC status. Specifically, $P M C_{i t}=$ treatment $*$ Post, treatment $=1$ if county I carried out the PMC reform during the sample period, and 0 otherwise.

The main empirical steps: first step, by using the above model, we analyze the treatment group (including 171 counties) from 1995 to 2008 and this step is

Table 1. Statistical analysis of dependent variables.

\begin{tabular}{ccccccc}
\hline Dummy variables & Dependent variables & count & mean & sd & $\min$ & $\max$ \\
\hline PMC & GDP growth & 1539 & 0.12 & 0.11 & -1.64 & 2.18 \\
Non-PMC & GDP growth & 8481 & 0.14 & 0.12 & -1.73 & 2.00 \\
\hline
\end{tabular}


mainly to study the short-term PMC reform practice effect. Second step, from 1995 to 2002 will be as an ex ante control, combining with the panel data from 2009 to 2012, using the above model analysis process. Then we compare the difference outcome and analyze the results of the first and second steps.

2) A random test of PMC pilot selection

Based on the sample of 1995-2002 years before reform, this paper uses Logit model to test the selection criteria of the selected counties. "Whether the province governing county" as the dependent variables and the conditions mentioned from the central and local government documents such as 2009, the Ministry of Finance-Document No. 78 "on the provincial supervision of County Finance Reform Opinions" mentioned that the grain and oil producing counties will be prior to select as reform county, such as, whether as a county-level City, whether as a poor county, whether as a food production County, whether asa province boundary County, altitude, slope, 1999 fiscal expenditure income ratio, non-agriculture population ratio as variables; examine whether these factors influence a county to be selected as the pilot reform.

According to Table 2 of Log it model regression results, we can find that the regression coefficient of the 8 variables mentioned above is statistically significant. According to the regression analysis, the 8 variables will affect the factors that have been chosen as a PMC county.

(3) Empirical results analysis

According to the estimation of the basic DID results in Table 3 column 1 and Table 3 column 2 shows, in the short term PMC reform has a statistically significant negative effect coefficient -0.028 , but in the long term this policy has a significant positive effect 0.029 .

\section{Interpretation}

Excessive government levels increase administrative levels and management costs and reduce administrative efficiency. The city has had an economic "crowding out effect" on the county, which has led to a growing gap between the urban and rural areas [9]. A large number of documents have analyzed the sources of the impact of the PMC reform on economic growth, there are two main aspects: first, fiscal decentralization, that is, decentralization of fiscal expenditure responsibility. Second, economic decentralization, that is, economic activities transferred from other counties and cities to the counties directly under the direct control of the city [10]. In addition, the expansion of the scope of provincial government power is an important source of the impact of the reform on the economic performance [11].

1) Financial transfer payment and fiscal revenue

As can be seen from Table 4, regardless of the short-term and long-term, the per capita financial transfer payments in the county are statistically and economically significantly increased due to the PMC reform under the jurisdiction of the province. The county tax refund per capita is a positive effect which is not statistically significant. Therefore, we believes that, in the short or long term, the reform has 
Table 2. Eight variables.

\begin{tabular}{|c|c|c|}
\hline variables & Explanation & PMC \\
\hline county_city & whether as a county-level City & $\begin{array}{r}-0.376^{* * *} \\
(0.075)\end{array}$ \\
\hline poor_county & whether as a poor county & $\begin{array}{l}0.155^{*} \\
(0.083)\end{array}$ \\
\hline food_county & whether as a food production county & $\begin{array}{c}0.373^{* * *} \\
(0.067)\end{array}$ \\
\hline Provboundary_county & whether asa province boundary county & $\begin{array}{l}0.280^{* * *} \\
(0.062)\end{array}$ \\
\hline slope & & $\begin{array}{c}0.151^{\star * *} \\
(0.007)\end{array}$ \\
\hline altitude & & $\begin{array}{r}-2.923^{* * *} \\
(0.223)\end{array}$ \\
\hline urban_rate00 & Non-agriculture population ratio & $\begin{array}{r}-0.021^{\star * *} \\
(0.003)\end{array}$ \\
\hline fiscal_gap99 & 1999 fiscal expenditure income ratio & $\begin{array}{r}-1.460^{\star * \star} \\
(0.081)\end{array}$ \\
\hline cut1 & & \\
\hline _cons & & $\begin{array}{l}-0.118 \\
(0.137)\end{array}$ \\
\hline $\mathrm{N}$ & & 18036 \\
\hline $\mathrm{R} 2$ & & \\
\hline
\end{tabular}

Standard errors in parentheses ${ }^{*} \mathrm{p}<0.10,{ }^{* *} \mathrm{p}<0.05,{ }^{* *} \mathrm{p}<0.01$.

made the county government allocate more funds. However, the government revenue is statistically significant negative effect. Finally, in the financial transfer payments and fiscal and taxation, we cannot discuss the reasons for the difference in the short-term and long-term economic growth.

2) Fiscal expenditure

Because of the government's infrastructure expenditure statistics by the end of 2006, the first column is the regression coefficient of the PMC reform and fiscal expenditure; the second column is the reform of the regression coefficient and infrastructure spending in Table 5. The results showed that in the short term, the reform make the financial expenditure decreased, but the infrastructure spending in the economy or whether statistics were significantly increased. Considering the characteristics of periodic long infrastructure, infrastructure spending will makes the benefit in the long term, so the reform of short-term economic growth has negative effect by the long-term positive effect it is logical.

3) The influence of PMC reform on social wealth 
Table 3. The impact of PMC reform on GDP growth.

\begin{tabular}{ccc}
\hline Dependent variable & $(1)$ & $(2)$ \\
\hline pmc & Short-term & Long-term \\
& growth & growth \\
Year fixed effect & -0.002 & $0.164^{* * *}$ \\
County fixed effect & $(0.010)$ & $(0.020)$ \\
treatment_trend & Yes & Yes \\
& Yes & Yes \\
cpe & $-0.004^{* * *}$ & $-0.010^{* * *}$ \\
& $(0.001)$ & $(0.002)$ \\
Control ${ }^{*}$ year dummy & 0.000 & $-0.013^{*}$ \\
L.lgdp & $(0.006)$ & $(0.007)$ \\
- cons & Yes & Yes \\
$N 2$ & & $0.087^{* * *}$ \\
$N$ & $0.045^{* * *}$ & $(0.012)$ \\
& $(0.016)$ & 11022 \\
\hline
\end{tabular}

Standard errors in parentheses ${ }^{*} \mathrm{p}<0.10,{ }^{* *} \mathrm{p}<0.05,{ }^{* * *} \mathrm{p}<0.01$.

The Table 6 above the first and third columns is the regression coefficient influence PMC reform on Farmers' income log, and the second and fourth columns is the reform regression coefficients of the urban wage effect. According to the results, in the short term, the PMC on Farmers' income is a significant negative effect and on urban wage level is no significant negative effect. By contrast, in the long term, the reform does not have a positive impact on Farmers' income, but is a significant positive effect on urban wage level. In the long-term reform, the urban population is more likely benefit from the PMC reform, so it is more likely to have a positive effect on economic growth. Therefore, the reform has raised the level of urban wages. According to macroeconomic analysis, wage increases will stimulate consumption to some extent, thereby stimulating investment and stimulating economic growth.

\section{Conclusions}

Using DID, we analyzed the impact on economic growth of the 2003 and 2004 a total of 171 PMC reform pilot and the reason to further strengthen the reform by government. We draw the following main conclusions:

1) In the short term, the PMC reform declined the GDP growth rate by 0.028 percentage points, and in the long run, the growth rate of GDP increased by 0.029 percentage points. This shows that in the long term, the PMC has a positive effect on economic growth, which explained the fact that govern 
Table 4. Financial transfer payment and fiscal revenue.

\begin{tabular}{|c|c|c|c|c|c|c|}
\hline \multirow[t]{2}{*}{ Dependent variable } & \multicolumn{3}{|c|}{ Short } & \multicolumn{3}{|c|}{ Long } \\
\hline & (1) & (2) & (3) & (4) & (5) & (6) \\
\hline \multirow{3}{*}{$\mathrm{pmc}$} & ltransfer & ltax & linc & ltransfer & ltax & linc \\
\hline & $0.615^{\star \star \star}$ & 0.072 & $-0.402^{\star * *}$ & $0.900^{* * *}$ & 0.153 & $-0.534^{\star * *}$ \\
\hline & $(0.120)$ & $(0.068)$ & $(0.053)$ & $(0.212)$ & $(0.133)$ & $(0.080)$ \\
\hline Year fixed effect & Yes & Yes & Yes & Yes & Yes & Yes \\
\hline County fixed effect & Yes & Yes & Yes & Yes & Yes & Yes \\
\hline \multirow[t]{2}{*}{ cpe } & $0.293^{\star *}$ & $0.089^{*}$ & $0.233^{* * *}$ & 0.139 & 0.164 & $0.293^{* * *}$ \\
\hline & $(0.119)$ & $(0.052)$ & $(0.036)$ & $(0.184)$ & $(0.116)$ & $(0.066)$ \\
\hline \multirow{2}{*}{ _cons } & $2.847^{* * *}$ & $3.453^{* * *}$ & $4.485^{\star * *}$ & $2.848^{* * *}$ & $3.453^{* * *}$ & $4.484^{* * *}$ \\
\hline & $(0.078)$ & $(0.033)$ & $(0.036)$ & $(0.078)$ & $(0.033)$ & $(0.033)$ \\
\hline$N$ & 14028 & 14028 & 14028 & 9018 & 9018 & 9018 \\
\hline$R 2$ & 0.521 & 0.641 & 0.696 & 0.466 & 0.640 & 0.674 \\
\hline
\end{tabular}

Standard errors in parentheses ${ }^{\star} \mathrm{p}<0.10,{ }^{* *} \mathrm{p}<0.05,{ }^{* *} \mathrm{p}<0.01$.

Table 5. Financial expenditure and infrastructure expenditure.

\begin{tabular}{ccc}
\hline & $(1)$ & $(2)$ \\
\hline pependent variable & lgovexp & lgovinvest \\
& $-0.077^{* * *}$ & $0.171^{\star * *}$ \\
treatment_trend & $(0.020)$ & $(0.038)$ \\
cpe & $-0.017^{* * *}$ & $-0.066^{* * *}$ \\
& $(0.004)$ & $(0.007)$ \\
cons & 0.006 & 0.028 \\
& $(0.021)$ & $(0.042)$ \\
$N 2$ & $5.435^{* * *}$ & $3.234^{* * *}$ \\
& $(0.007)$ & $(0.015)$ \\
\hline
\end{tabular}

Standard errors in parentheses ${ }^{\star} \mathrm{p}<0.10,{ }^{* *} \mathrm{p}<0.05,{ }^{* * *} \mathrm{p}<0.01$.

ment issued a document to further promote the reform of the PMC reform in 2009.

2) The PMC reform mainly affects the growth rate of GDP through the government revenue, financial expenditure, and the level of social wealth.

3) The main cause of the different effects one economic growth is that: firstly, in the short term the effect of infrastructure spending growth is lag, but the long-term it will benefit; secondly, the reform makes the urban wage increase, and promotes consumption in the long term. Therefore the total of investment will increase, and then will have a positive impact on economic growth. 
Table 6. The influence of PMC reform on social wealth.

\begin{tabular}{ccccc}
\hline & Short & Short & Long & Long \\
\hline & $(1)$ & $(2)$ & $(3)$ & $(4)$ \\
\hline pmc & lrinc & lwage & lrinc & lwage \\
& $-0.036^{* * *}$ & -0.010 & $-0.056^{* * *}$ & $0.021^{*}$ \\
Year fixed effect & $(0.013)$ & $(0.008)$ & $(0.017)$ & $(0.012)$ \\
County fixed effect & Yes & Yes & Yes & Yes \\
Ycons & Yes & Yes & Yes & Yes \\
& $7.475^{* * *}$ & $8.664^{* * *}$ & $7.475^{* * *}$ & $8.664^{* * *}$ \\
N & $(0.005)$ & $(0.004)$ & $(0.005)$ & $(0.004)$ \\
R2 & 13404 & 13460 & 10722 & 10753 \\
& 0.924 & 0.902 & 0.933 & 0.957 \\
\hline
\end{tabular}

Standard errors in parentheses. ${ }^{\star} p<0.10,{ }^{* *} p<0.05,{ }^{* *} p<0.01$.

On the basis of a large number of provincial and ministerial reform studies, we explored the central government's intention to further strengthen the reform of PMC in 2009. Although the reform did not achieve the goal of economic growth in the short term, in the long run, it will benefit from reform. So far, the conclusion of this paper is consistent with the enthusiasm and prudence of the government in implementing the reform in practice.

However, in practice, Hebei announced new eight provinces straight county (city) pilot to make re-adjustment that 8 counties (cities) no longer carry out PMC in March 2015. As the first batch of Hebei Province, Dingzhou, Xinji has been a PMC about two years. You can find new pilot practice for a variety of reasons is very short. Because the lack of data this paper do not find out the reason of discarding the PMC reform by Hebei. Much remain to be done. A deeper analysis of PMC reform is an exciting avenue for future research.

\section{References}

[1] Qian, Y., Roland, G. and Xu, C. (2006) Coordination and Experimentation in M-Form and U-Form Organizations. Journal of Political Economy, 114, 366-402. https://doi.org/10.1086/501170

[2] Liu, Y. and Alm, J. (2015) Fiscal Reform, Land Expansion, and Urban Growth in China. Working Paper, School of Finance Renmin University of China, Beijing.

[3] Li, P., Lu, Y. and Wang, J. (2016) Does Flattening Government Improve Economic Performance? Evidence from China. Journal of Development Economics, 123, 18-37. https://doi.org/10.1016/j.jdeveco.2016.07.002

[4] Jia, J.X., Zhang, Y.J. and Guo, J. (2013) The Fiscal System Reform on Direct Province Control of Counties, Counties' Economic Growth and the Overcome of Fiscal Difficulties. China Soft Science Magazine, 6, 22-29. (in Chinese)

[5] Chen, S.X. and Lu, S.F. (2014) Does Decentralization Increase the Public Services Expenditures: A Quasi-Experiment of "County Administrated by Province" in China. China Economic Quarterly, 13, 1261-1282. (in Chinese) 
[6] Cai, W.G. and Huang, L.X. (2010) The Determinants and Economic Impacts of Government Flattening Reform. Management World, 8, 73-83. (in Chinese)

[7] Cai, H., Henderson, J.V. and Zhang, Q. (2013) China's Land Market Auctions: Evidenceof Corruption? The RAND Journal of Economics, 44, 488-521.

https://doi.org/10.1111/1756-2171.12028

[8] Fitzgerald, J. (2002) Rethinking China's Provinces. Routledge, London and New York.

[9] Zheng, X.Y., Wang, H. and Zhao, Y.Z. (2011) Does Province-Managing-County Reform Promote Economic Growth? A Difference-in-Difference Approach. Management World, 8, 34-44.

[10] Weingast, B.R. (2009) Second Generation Fiscal Federalism: The Implications of Fiscal Incentives. Journal of Urban Economics, 65, 279-293. https://doi.org/10.1016/j.jue.2008.12.005

[11] Chen, T. and Kung, J.K. (2015) Do Land Revenue Windfalls Create A Political Resource Curse? Evidence from China. Working Paper, Hong Kong University of Science and Technology, Hong Kong. 